\title{
LABOR PRODUCTIVITY CONVERGENCE OR DIVERGENCE IN TRANSITION COUNTRIES BEFORE AND AFTER THE COLLAPSE OF SOVIET UNION*
}

\section{SOVYETLER BİRLİĞINIIN YIKILMASINDAN ÖNCEKİ VE SONRAKİ DÖNEMDE GEÇIŞ ÜLKELERININ EMEK VERIMLILİĞİ YAKINSAMASI YA DA IRAKSAMASI}

Arş. Gör. Gül Ş. HUYUGUZEL KISLA, Prof. Dr. Ertugrul DELIKTAS, Ege Üniversitesi İktisadi ve İdari Bilimler Fakültesi, İktisat Bölümü, gul.kisla@ege.edu.tr, ertugrul.deliktas@ ege.edu.tr

\section{Abstract:}

This study examines labor productivity convergence in the Former Soviet Union Countries. It is known that labor productivity is a key of measure of economic growth and national competitiveness. The study includes two periods: first period covers the 1970-1989 years, and second period includes the 1991-2010 years called as the transition period. The findings of study indicate that during the Soviet Union, the speed of labor productivity convergence for fifteen countries is almost zero. On the other hand, according to conditional convergence model labor productivity levels have slowly converged towards the steady-state levels during the transition period. The convergence speed for the transition period is 0.021 for fixed effect pooled least squares model and is 0.115 for GMM model.

Key words: convergence, labor productivity, Soviet Union Countries, transition economies

$\underline{\text { Özet: }}$

Bu çalışmada daha önceleri Sosyetler Birliği olarak anılan ülkelere ait emek verimliliği yakınsaması analiz edilmiştir. Bilindiği üzere emek verimliliği ekonomik büyümenin ve ulusal rekabetin önemli bir ölçütüdür. Bu çalışmada, 1970-1989 dönemi il geçiş dönemi olarak adlandırılan 1991-2000 dönemi dikkate alınmıştır. Sosyetler Birliği döneminde emek verimlililiği yakınsama hızı neredeyse sıfir olarak bulunmuştur. Diğer yandan, koşullu yakınsama sonuçlarına göre, geçiş sürecinde ülkelerin emek verimlilikleri durağan durum düzeyine yakınsamıştır. Yakınsama hızı sabit etkili model için 0.021; GMM modeli için 0.115 olarak bulunmuştur.

Anahtar Kelimeler: yakınsama,emek verimliliği, Sovyetler Birliği ülkeleri, geçiş ekonomileri

* This study is derived from Gul S. Huyuguzel Kisla's master thesis and another version is presented in the International Congress on Economics Finance and Banking, 26-28 June 2013. 


\section{INTRODUCTION}

This paper examines economic performance of the Former Soviet Union Countries (FSUCs) ${ }^{1}$ using labor productivity convergence approach by considering two periods, namely pretransition period (1970-1989) and transition period (1991-2010). Labor productivity convergence is based on aggregate average labor productivities of the countries examined. Labor productivity convergence among the transition economies is important in order to evaluate the success of transition process. However, in this paper, we are not directly comparing two periods in terms of labor productivity because of data heterogeneity. Rather, we aim to analyze the labor productivity convergence for each period separately.

The subject of this study is important because the Soviet Union grew rapidly through the mid of 1970 s due to rapid and successful planned capital accumulation ${ }^{2}$. Therefore, a powerful rivalry occurred between the Soviet Union and the United States until 1980s (Case and Fair, 2004). However, in the mid of 1980s, the political and economic structures of the Soviet Union and the Eastern European planned countries started to crumble and by the end of 1991 the Soviet Union collapsed. Then, the countries ruled under the Soviet Union declared their independences and decided to transform from planned economy to market-based economy. This process has been called as the transition process in the literature. It has been suggested that the most important economic reason of the transition was the ever-worsening economic inefficiency during the Soviet period due to wrong, inefficient, and irrational planning decisions. Therefore, it is expected that economic efficiency would increase after transition to the market economy due to competition and efficient use of input resources. However, at the first stage of transition the labor productivity, economic growth, and production efficiency decreased until 1997 for most countries. Some transition economies recovered pre-transition GDP levels only after 2000 (Deliktas and Balcilar, 2005).

The transition process has caused not only economical changes but also social and political changes in the countries. According to Roaf et al. 2014, all countries suffered from high inflation and major recessions at first years of the transition. Therefore, we can easily say that the transition period is costly for citizens, firms and governments at first sight. This period should be managed successfully especially by the governments of the transition economies.

According to some analysts such as Lipton and Sachs (1990), Hinds (1990), establishing the market economy in transitional economies mainly depends on four inter-related policies on the micro-economic side: price liberalization, integration to the world economy, reducing barriers to entry by new firms and privatization (Deliktas and Emsen, 2002). It is expected that these policies would stimulate economic growth through labor productivity growth. Because, with transition to market economy, labor productivity and efficiency will increase due to private-owned enterprises, independent financial institutions and more competition. Therefore, increases in labor productivity and production efficiency will cause output to

\footnotetext{
${ }^{1}$ These countries are Armenia, Azerbaijan, Belarus, Estonia, Georgia, Kazakhstan, Kyrgyzstan, Latvia, Lithuania, Moldova, Russian Federation, Tajikistan, Turkmenistan, Ukraine and Uzbekistan.

${ }^{2}$ The Soviet Union's economy was growing much faster than that of the United states during the late 1950s (Case and Fair, 2004).
} 
increase. Output growth in transition economies can also be thought in terms of improvement in technical efficiency, technological progress or total factor productivity growth (Osiewalski et al. 1998).

It is highly important to measure and to evaluate labor productivity convergence among economies due to more competitive world. The term "convergence" is known as the tendency for two or more economies to become more similar in terms of their per capita income, output growth rate, improvement in economic efficiency, and total factor productivity growth or other measures (Kok and Deliktas, 2004). Convergence can also be thought as a tendency of poor countries/ regions to become rich over time or whether rich countries /regions would be also rich in the future. This concept can be analyzed and understood in different ways which are (Islam, 2003):

a) convergence within an economy vs. convergence across economies

b) convergence in terms of growth rates vs. convergence in terms of income level

c) absolute convergence vs. conditional convergence

d) income convergence vs. total factor productivity convergence

e) Deterministic convergence vs. stochastic convergence

Even all these ways to understand the convergence has been used, mostly absolute and conditional convergence are applied in order to analyze the disparities between the countries or regions. Beta convergence can be defined as the poor countries tend to have higher growth rates with regard to rich ones. According to Sala-i Martin (1996), there is beta convergence in which the relationship between the growth rates and the initial income levels are negative. The relationship between the growth rate and the initial income level can be shown as;

$$
\log \left(y_{i, t+T} / y_{i, t}\right) / T=\alpha-\beta \log \left(y_{i, t}\right)+\varepsilon_{i, t+T}
$$

This equation can be evaluated for the absolute convergence. The sign of the initial income level is used to judge whether there is beta convergence $(\beta>0)$ or not. When the economies have similar saving rates, institutional structures and technologies, then they have the same steady-state level. On the other hand, when the saving rates, institutional structures and technologies of the countries are different from each other, then they have their own steadystate levels. In this case, the conditional convergence will be valid. In case of conditional convergence, the equation for the absolute convergence can be rewritten as

$$
\log \left(y_{i, t+T} / y_{i, t}\right) / T=\alpha-\beta \log \left(y_{i, t}\right)+\psi X_{i, t}+\varepsilon_{i, t+T}
$$

in which "Xit" shows the vector of variables in order to use to stabilize the steady state level.

In the literature there are some studies concerning the issues about growth, performance measurement, and convergence of nations. These studies can be divided into three main approaches. The first approach focuses on the growth in real per capita income or real GDP per capita. The second approach deals with the extent of convergence achieved by the poor countries and measure disparities in the global distribution of income. The third approach is 
about productivity performance of decision making units, such as labor productivity or total factor productivity (Rao et al. 1998).

There are a plenty of studies on GDP per capita or productivity convergence in the literature, however, there are few studies focusing on the convergence issue in transition economies. For example, Abramovitz (1986) studied $\beta$-convergence of labor productivity of sixteen advanced countries for 1870-1979 periods. Baumol and Wolff (1988) examined sigma convergence for the nineteen European countries for the period 1830-1913. Baumol (1986) examined productivity convergence in both industrialized and the less developed countries. The industrialized countries experienced labor productivity convergence, while the others experienced divergence. Dowrick and Nguyen (1989) studied the sigma convergence in the OECD countries for the period 1950-1985 and they concluded that there was a sigma convergence in total factor productivities of the OECD countries. Yurtsever (2007) analyzed the sectoral labor productivity convergence for 14 European countries for the period 19792003 and found evidence of convergence in all sectors. Matheson and Oxley (2007) studied sectoral labor productivity convergence in New Zeland and Australia. They found that some sectors experience divergence while some sectors have conditional convergence. Actually the sectors, regions, and countries with low initial capital stocks and income levels could have higher returns to capital. Tansel and Güngör (1997) examined labor productivity convergence for the period 1975-1995 at provincial level in Turkey. They found that there is absolute convergence.

Some studies focused on the transition economies. For example, Kok and Deliktas (2004) examined the technical efficiency convergence in 25 transition economies for the period 1991-2003 and concluded that the less efficient countries at the beginning of the period converged toward the steady stade level at the end of study period. Polanec (2004) studied absolute and conditional convergence in transition economies for the period 1990-2002. He divided the study period into three sub-periods and concluded that there was absolute and conditional convergence only for the period 1998-2002. Polenec (2007) studied absolute and conditional convergences in productivity growth of 25 transition countries for the period 1990-2002. He concluded that the productivity growth in early transition (1990-1994) is positively related to initial productivity level (divergence), however, there is a convergence for the period 1998-2002.

Apart from these studies, we try to analyze the labor productivity convergence in the two sub periods, namely for the pre-transition period and for the transition period covering the 15 transition economies data. We use average labor productivities(Y/L) and some transition indicators for the estimations. We make analyses for the absolute convergence, conditional convergence with the help of OLS and GMM methods. We also add sigma convergence results for supporting beta convergence analysis. For the conditional convergence, we benefit from transitional variables. According to the estimation results, we have found labor productivity divergence for the pre-transition period and labor productivity convergence for the transition period. This result is consistent with our expectations which presume that before the transition period, countries will diverge from each other. However, after the transition process, countries will converge to each other in case of labor productivity. With the help of 
our results, we can say that our study is quite important because labor productivity is crucial in growth dynamics and in order to understand the growth performances of transition economies, it could be better to compare the convergence dynamics of transition countries for different periods. The remainder of the paper is as fallows. The second section briefly outlines the major sources of data and describes all the variables used in the study. The third section defines the methodology used in the analysis. The fourth section presents empirical results and the fifth section concludes the paper.

\section{DATA}

In this study we have studied labor productivity convergence for 15 transition economies which are Armenia, Azerbaijan, Belarus, Estonia, Georgia, Kazakhstan, Kyrgyzstan, Latvia, Lithuania, Moldova, Russian Federation, Tajikistan, Turkmenistan, Ukraine and Uzbekistan. We analyze the labor productivity convergence before (1970-1989) and after the collapse of the Soviet Union (1991-2010). In this respect, for the period of 1970-1989, we use employment (L) and NMP (Net Material Product) in 1973 constant rubles in order to calculate average labor productivity. All data is provided mainly by the Centre of Economic Analysis and Forecasting in Moscow.

The labor productivity for the pre-transition period (1970-1989) is given in Figure 1. According to Figure 1, we can easily say that the labor productivity has slightly risen in this period.

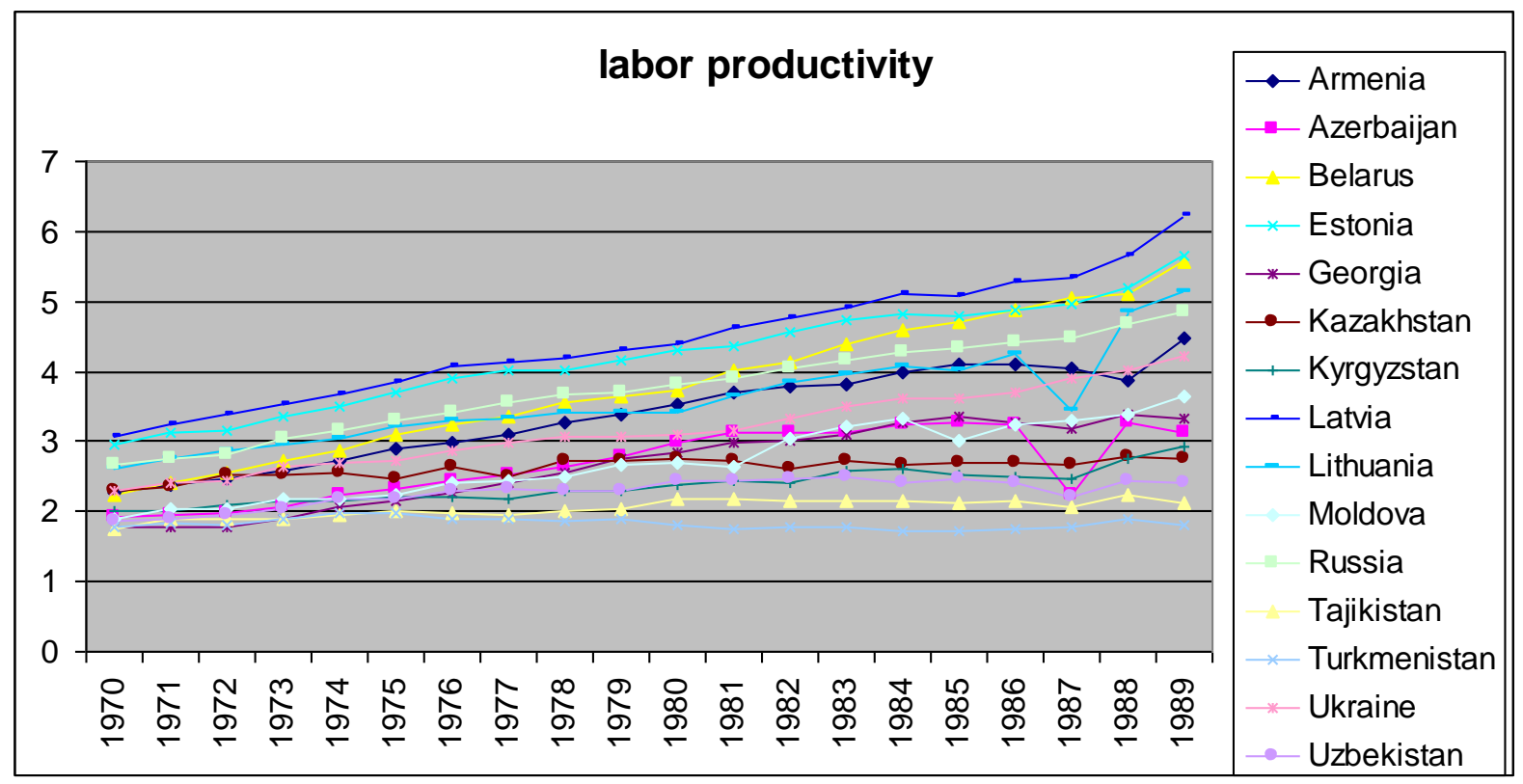

Figure 1: Labor Productivity in Period 1970-1989

Source: Authors' calculations.

On the other hand, when we consider the period of 1991-2010, aggregate output (Y) is measured by GDP (constant 2000\$) and labor input (L) is measured by employment. Data for the aggregate output is obtained from World Development Indicators (2012), unemployment 
rates are taken from EBRD (European Bank for Reconstruction and Development) and ILO (International Labor Organization), The employment data are calculated from the labor force and unemployment rates.

The average labor productivity (Y/L) for the transition economies for the period 1991-2010 is represented in the Figure 2. According to Figure 2, labor productivity decreased until 1994. Between the period of 1994-2004, labor productivity increased steadily. After a slightly decrease in 2005, the labor productivity has rised again until the year of 2008.

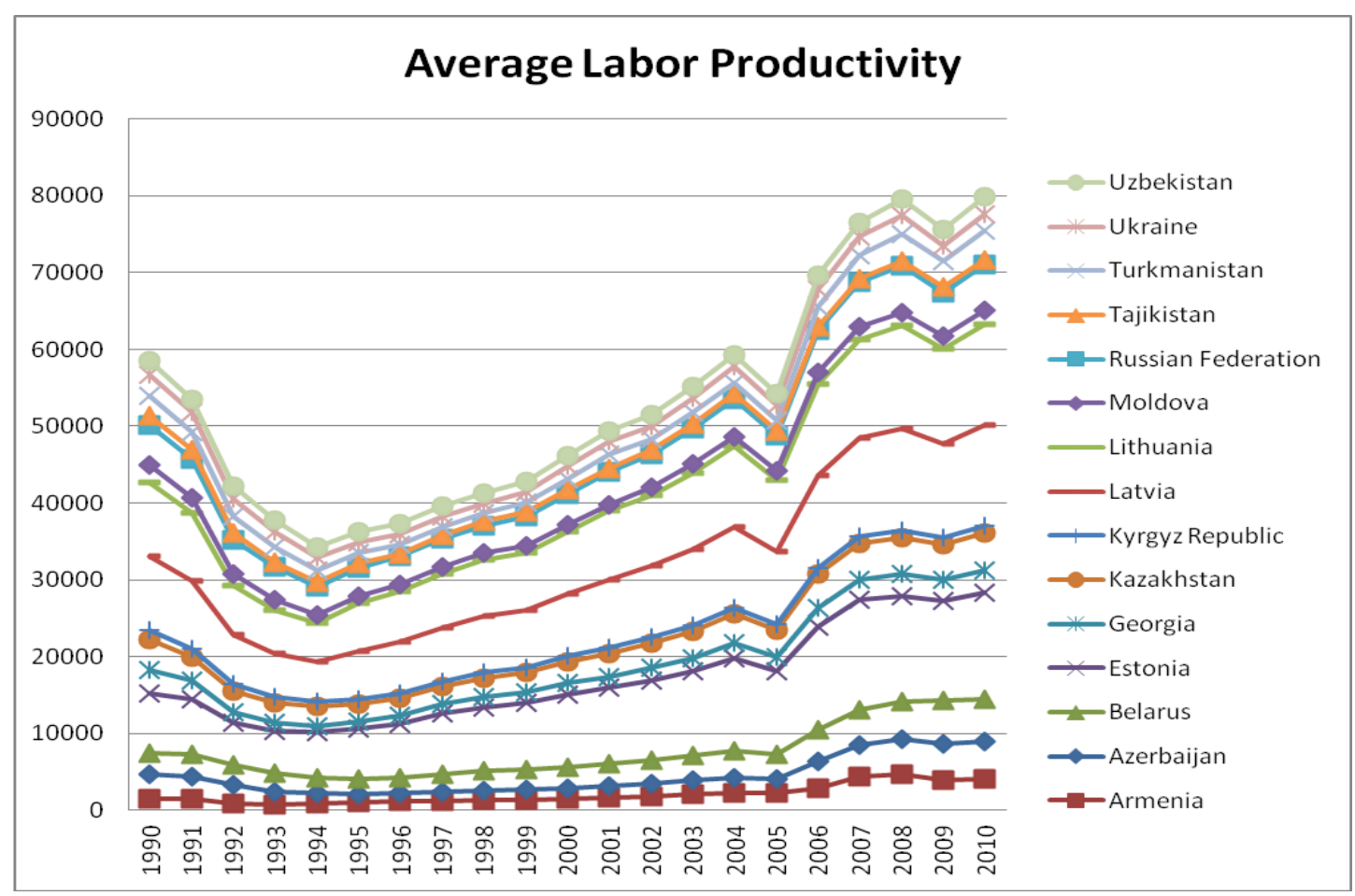

Figure 2: Labor Productivity in period 1991-2010

Source: Authors' calculations.

For transition period we also consider some transition indicators like large scale privatization $(L S P)$, small scale privatization (SSP), governance enterprise restructuring (ENR), price liberalization (PRL), trade and forex system (TRD), competition policy (COM) to use in the analysis of conditional convergence. These indicators range from 1 (central planning economy) to 4+(industrialized market economy) and can be found at EBRD's website. For the pre-transition period, we do not have any such data. Therefore, we only analyze absolute convergence and sigma convergence for the period 1970-1989, whereas absolute, conditional and sigma convergences are analyzed for the period 1991-2010.

\section{METHODOLOGY}

In this study, we use beta convergence and sigma convergence approaches based on panel data to analyze the labor productivity convergence between transition economies for two sub periods, 1970-1989 and 1991-2010. Barro and Sala-i Martin (2004) used the initial income levels and growth rates in convergence model while some researchers use the lagged of 
dependent variable as an explanatory variable in panel data analysis. ${ }^{3}$ Therefore, we will use equation (3) for the absolute convergence and the equation (4) for the conditional convergence (Beta convergence);

$$
\begin{aligned}
& \log \left(\operatorname{LP}_{\mathrm{i}, \mathrm{t}}\right)=\alpha+\beta \log \left(\mathrm{LP}_{\mathrm{i}, \mathrm{t}-1}\right)+\varepsilon_{\mathrm{i}, \mathrm{t}} ; \\
& \log \left(\mathrm{LP}_{\mathrm{i}, \mathrm{t}}\right)=\alpha+\beta \log \left(\mathrm{LP}_{\mathrm{i}, \mathrm{t}-1}\right)+\psi \mathrm{X}_{\mathrm{i}, \mathrm{t}}+\varepsilon_{\mathrm{i}, \mathrm{t}}
\end{aligned}
$$

where "LP" is the average labor productivity. When the coefficient of "log (LP i,t-1)" is positive and smaller than 1 , it will be the evidence of labor productivity convergence, but if it is bigger than 1, then there is an evidence of divergence. In the second model, "Xi,t" includes indices large scale privatization (LSP), small scale privatization (SSP), governance enterprise restructuring (ENR), price liberalization (PRL), trade and forex system (TRD), competition policy (COM). In order to show the existence of labor productivity convergence or divergence, we use OLS (Ordinary Least Square) Method and GMM (Generalized Methods of Moments) in our estimations. Because of the lagged dependent variables in the equation 1 and 2, we gave importance to GMM results rather than OLS results. According to Hsiao (2003), when dynamic panel data is used, it could be better to use GMM rather than OLS. The main reason behind this choice is that estimated coefficients will be unbiased and consistent under the selection of GMM. We use instrumental variables in our GMM estimations. In addition to beta convergence estimations, we calculate variation coefficients for the sigma convergence. Sigma convergence can be thought as the decreasing dispersion of labor productivities over time (Lall and Y1lmaz, 2000). According to sigma convergence, if the variation coefficients are increasing (decreasing) year by year, we can easily conclude that there is a beta divergence (convergence) for the labor productivity.

\section{EMPIRICAL RESULTS}

In this section we provide estimation results for the absolute and conditional convergence considering the pre-transition and transition periods. Also, sigma convergence will be provided for both periods. Because of the lack of data, we consider only absolute convergence for the pre-transition period whereas both convergence types are included for the transition period.

\section{Estimation of absolute convergence coefficient for pre-transition period}

Table 1 contains estimation results for the fixed effect OLS model and GMM model. The decision of whether countries converged in terms of labor productivity depends on lagged values of labor productivity variable.

\footnotetext{
${ }^{3}$ An interested reader can look at the studies of Lall and Y1lmaz(2000); Onder, Deliktas and Karadag (2006) and Islam (1995) for the further implications of the models.
} 
Table 1: Absolute convergence for the pre-transition economies for the period 1970-1989

\begin{tabular}{|c|c|c|}
\hline \multirow{2}{*}{$\begin{array}{l}\text { Explanatory } \\
\text { Variables }\end{array}$} & \multicolumn{2}{|c|}{ Dependent variable :Labor productivity } \\
\hline & $\begin{array}{c}\text { Model 1 } \\
\text { (Fixed Effect OLS) }\end{array}$ & $\begin{array}{l}\text { Model } 2 \\
(\text { GMM) }\end{array}$ \\
\hline Constant & $\begin{array}{c}0.0983 \\
(5.4286)\end{array}$ & $\begin{array}{l}-0.0014 \\
(0.1618)\end{array}$ \\
\hline Laborprd $_{(-1)}$ & $\begin{array}{l}0.9411 * \\
(61.384)\end{array}$ & $\begin{array}{c}1.0261 * \\
(147.852)\end{array}$ \\
\hline Adj. $R^{2}$ & 0.9890 & 0.9878 \\
\hline F-statistic & 1710.87 & \\
\hline Akaike info.criterion & -2.9307 & \\
\hline
\end{tabular}

$\mathrm{t}$ - Statistics are given in parenthesis, and * indicates that the related parameter is statistically significant at 5\% significance level.

Source: Authors' calculations.

According to table 1, fixed effect OLS model indicates that there is a slightly beta convergence in the pre transition period for the 15 formerly Soviet Union countries. However, the estimation results for the GMM model prove that there is a labor productivity divergence in this period.

\section{Sigma Convergence for pre-transition period}

In order to support the analysis of beta convergence, we include the sigma convergence for this period. In this respect, we calculate the variation coefficients year by year using the standard deviation of $\log$ (LP) and mean of $\log$ (LP). Table 2 and figure 3 show calculated variation coefficients for the pre-transition period. According to the results, we can easily say that there is no labor productivity convergence for the pre-transition period. Actually, after the year of 1980, the variation coefficient is getting higher until 1987 indicating the labor productivity divergence.

Table 2: Coefficient of Variation for 1970-1989

\begin{tabular}{|c|c|c|c|c|}
\hline Years & Coefficient of Variation & & Years & Coefficient of Variation \\
\hline 1970 & 23,81806 & 23,70384 & 1980 & 22,96758 \\
\hline 1971 & 24,30302 & 1981 & 24,56341 \\
\hline 1972 & 23,73795 & 1982 & 25,05253 \\
\hline 1973 & 22,36196 & 1983 & 25,1259 \\
\hline 1974 & 23,16232 & 1984 & 26,34205 \\
\hline 1975 & 23,73352 & 1985 & 26,86529 \\
\hline 1976 & 24,19426 & 1986 & 27,3509 \\
\hline 1977 & 23,66643 & 1987 & 30,41362 \\
\hline 1978 & 23,4145 & 1988 & 26,52367 \\
\hline 1979 & & 1989 & 29,54891 \\
\hline
\end{tabular}




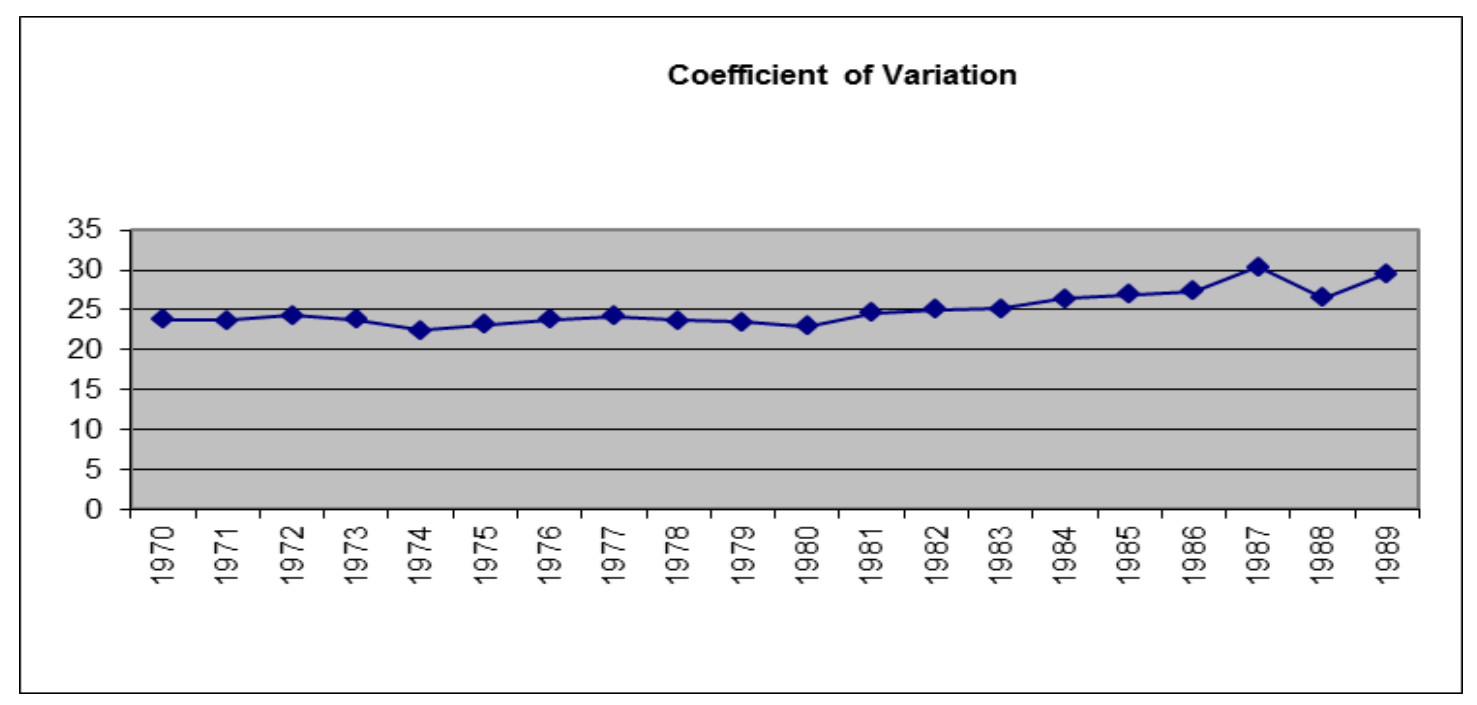

Figure 3: Coefficient of Variation for 1970-1989

Source: Authors' calculations.

\section{Estimation of convergence coefficient for transition period}

In this section, we present the absolute and conditional convergence results for the transition period. Sigma convergence results are also included.

\section{Absolute convergence}

Table 3 shows the estimation results of the absolute convergence. According to table 3, both models indicate divergence in labor productivity over the period of 1991-2010.

Table 3: Absolute labor productivity convergence for transition economies for the period 1991-2010

\begin{tabular}{|l|c|c|}
\hline \multirow{2}{*}{$\begin{array}{c}\text { Explanatory } \\
\text { Variables }\end{array}$} & Dependent variable: labor productivity \\
\cline { 2 - 3 } & $\begin{array}{c}\text { Model 1 } \\
\text { (Fixed Effect OLS) }\end{array}$ & $\begin{array}{c}\text { Model 2 } \\
\text { (GMM) }\end{array}$ \\
\hline Constant & $-0.460^{*}$ & -0.0413 \\
& $(2.418)$ & $(0.571)$ \\
\hline Laborprd $_{(-1)}$ & $1.064^{*}$ & $1.007^{*}$ \\
& $(41.030)$ & 0.976 \\
\hline Adj. $\mathrm{R}^{2}$ & 0.854 & \\
\hline F-statistic & 112.135 & \\
\hline Akaike info.criterion & -2.698 & \\
\hline
\end{tabular}

$\mathrm{t}$ - Statistics are given in parenthesis, and * indicates that the related parameter is statistically significant at 5\% significance level

Source: Provide relevant reference or state "Authors' calculations.”

\section{Conditional convergence}

In this section, we include some explanatory variables called transition variables in order to test the evidence of conditional convergence., These variables are as fallows; namely large scale privatization (LSP), small scale privatization (SSP), governance enterprise 
restructuring (ER), price liberalization (PRL), trade and forex system (TRD), competition policy $(C O M){ }^{4}$

Before running our estimations, we has checked the transition indicators whether there is a multicollinearity problem between them or not. Even if there are some degree of multicollinearity between transition variables like LSP and SSP, we want to add these variables in order to see their effects on the labor productivity. According to conditional convergence approach, models 1 and 2 indicate beta convergence in labor productivity for transition economies. Convergence speeds ${ }^{5}$ are 0.214 , and 0.115 , respectively. Model 2 has low convergence speed compared to model 1 . When we look at the results for the model 1, we can conclude that the coefficients for SSP, ER, and TRD are found to be positive. However, LSP, PRL, and COM have negative effect on labor productivity. Except LLP, all of the variables are found to be significant at $5 \%$ significance level.

In model 2; SSP, ENR, PRL, TRD, and COM have positive effect on labor productivity but LSP has negative effect. However, in contrast to model 1, ER, PRL, and COM are found to be statistically insignificant.

Table 4: Conditional labor productivity convergence for transition economies for the period 1991-2010

\begin{tabular}{|c|c|c|}
\hline \multirow{2}{*}{$\begin{array}{l}\text { Explanatory } \\
\text { Variables }\end{array}$} & \multicolumn{2}{|c|}{ Dependent variable: labor productivity } \\
\hline & $\begin{array}{c}\text { Model 1 } \\
\text { (Fixed Effect) }\end{array}$ & $\begin{array}{l}\text { Model 2 } \\
\text { (GMM) }\end{array}$ \\
\hline Constant & $\begin{array}{l}1.429^{*} \\
(3.919) \\
\end{array}$ & $\begin{array}{l}0.495^{*} \\
(2.540)\end{array}$ \\
\hline Laborprd $_{(-1)}$ & $\begin{array}{c}0.807^{*} \\
(17.296)\end{array}$ & $\begin{array}{c}0.891^{*} \\
(36.120)\end{array}$ \\
\hline $\operatorname{LSP}_{(-1)}$ & $\begin{array}{l}-0.0528 \\
(1.653)\end{array}$ & $\begin{array}{l}-0.044 * \\
(2.125)\end{array}$ \\
\hline $\operatorname{SSP}_{(-1)}$ & $\begin{array}{l}0.139^{*} \\
(4.261) \\
\end{array}$ & $\begin{array}{l}0.069^{*} \\
(3.538) \\
\end{array}$ \\
\hline $\mathrm{ER}_{(-1)}$ & $\begin{array}{l}0.047^{*} \\
(1.974) \\
\end{array}$ & $\begin{array}{c}0.040 \\
(1.370) \\
\end{array}$ \\
\hline $\mathrm{PRL}_{(-1)}$ & $\begin{array}{l}-0.021^{*} \\
(2.623)\end{array}$ & $\begin{array}{c}0.014 \\
(0.933) \\
\end{array}$ \\
\hline $\operatorname{TRD}_{(-1)}$ & $\begin{array}{l}0.025^{*} \\
(2.157) \\
\end{array}$ & $\begin{array}{l}0.034 * \\
(2.026) \\
\end{array}$ \\
\hline $\mathrm{COM}_{(-1)}$ & $\begin{array}{l}-0.181^{*} \\
(5.430)\end{array}$ & $\begin{array}{c}0.012 \\
(0.569)\end{array}$ \\
\hline Adj. $\mathrm{R}^{2}$ & 0.927 & 0.9890 \\
\hline F-statistic & 174.381 & \\
\hline Akaike info.criterion & -3.371 & \\
\hline
\end{tabular}

t- Statistics are given in parenthesis, and * indicates that the related parameter is statistically significant at 5\% significance level. For the GMM model, we use second lagged values of the transition indicators as the instrumental variables. Source: Authors' calculations.

\footnotetext{
${ }^{4}$ We tried to add another explanatory variable called "capital intensity" but there are some lack of capital intensity data for some countries like Lithuania and Moldova.

${ }^{5}$ Convergence speeds can be calculated as taking the natural logaritm of $\beta(-\ln \beta)$.
} 


\section{Sigma Convergence for transition period}

According to table 5, we have found labor productivity divergence from 1991 to 1998. However it is obvious that after 2001, there is a sigma convergence of labor productivity between transition economies until the year of 2009. This result is consistent with the transition economies' perspective to reforms applied. The behavior of coefficient of variation is also seen in Figure 4.

Table 5: Coefficient of Variation for transition period

\begin{tabular}{|c|c|}
\hline Years & Coefficient of Variation \\
\hline 1991 & 69.28 \\
\hline 1992 & 65.86 \\
\hline 1993 & 70.44 \\
\hline 1994 & 79.95 \\
\hline 1995 & 89.23 \\
\hline 1996 & 93.31 \\
\hline 1997 & 95.89 \\
\hline 1998 & 96.67 \\
\hline 1999 & 95.70 \\
\hline 2000 & 97.39 \\
\hline 2001 & 97.40 \\
\hline 2002 & 97.17 \\
\hline 2003 & 96.26 \\
\hline 2004 & 96.73 \\
\hline 2005 & 94.88 \\
\hline 2006 & 92.31 \\
\hline 2007 & 88.63 \\
\hline 2008 & 83.39 \\
\hline 2009 & 81.24 \\
\hline 2010 & 82.42 \\
\hline
\end{tabular}

Source: Authors' calculations. 


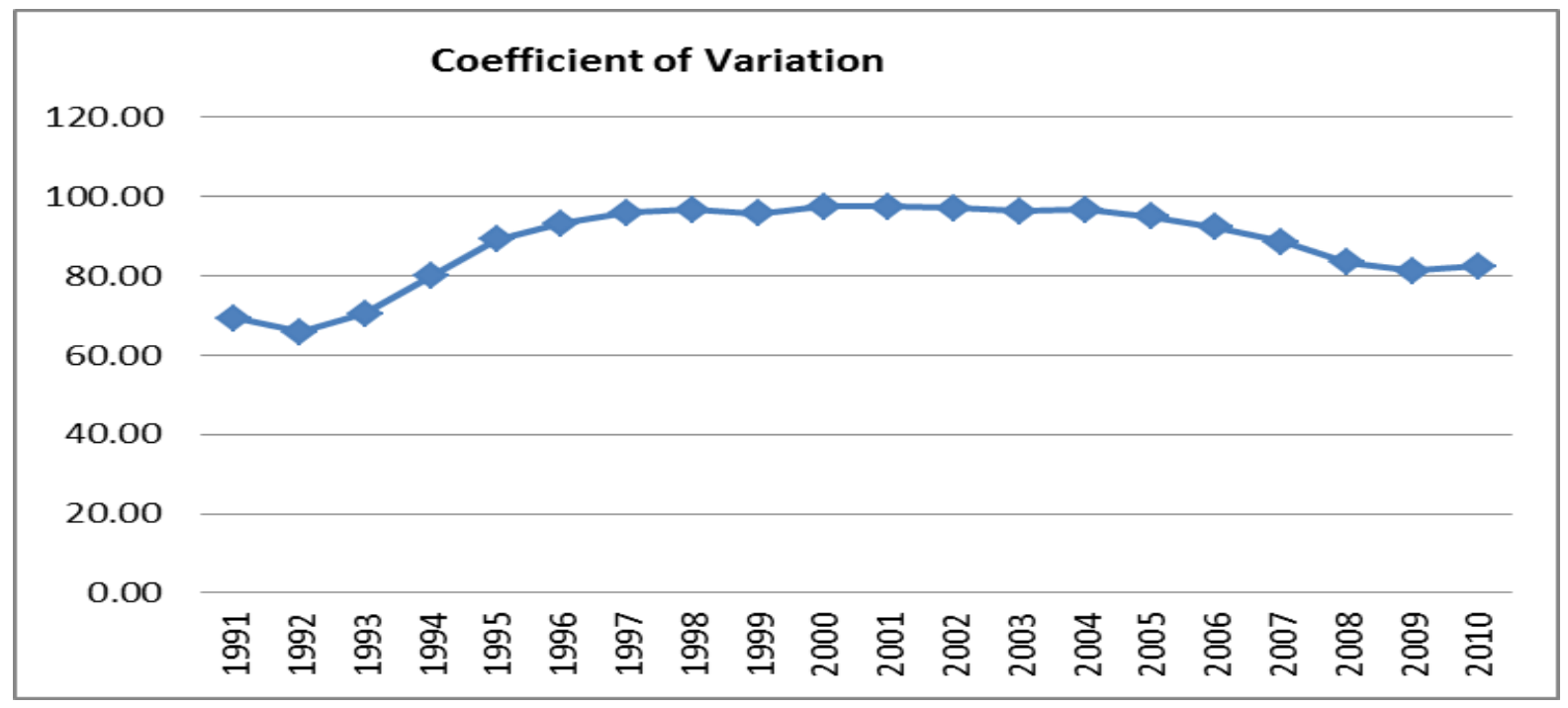

Figure 4: Variation Coefficient of Variation for 1991-2010

Source: Authors' calculations.

\section{CONCLUSION}

In this paper, we tried to confirm that there is a difference between the pre-transition and the transition period for the FSU countries in terms of their productivity performance. The reason behind this study is to figure out whether the FSU countries become successful when they changed their economic structure from planned economy to market economy. In order to analyze the pre-transition and transition periods, we take into account two periods which are 1970-1989 and 1991-2010. For this reason, we benefit from 15 transition countries' labor productivity data concerning the two sub-periods in order to understand their convergence pattern. We know that the researchers dealing with the convergence issue are generally focused on beta convergence hypothesis and sigma convergence hypothesis. Therefore, we prefer to analyze the labor productivity convergence by using beta and sigma convergence correspondingly. According to estimation results of various regressions and calculated variation coefficients, we found that there is a slightly labor productivity divergence especially at the end of 1980s for pre-transition period. Because of the limitation of data for pre-transition period, we could only concentrate on the absolute and sigma convergence for this period. However, by the availability of data, we use some transition indicators as the explanatory variables in the conditional convergence regression for the transition period. In the transition period, absolute convergence analysis shows that there is a divergence of labor productivity for the both models. However, conditional convergence analysis supports the idea of convergence in both fixed effect OLS and GMM model. The result of sigma convergence supports this fact partially. When we look at the estimation results, we found that small scale privatization, enterprise restructuring and trade $\&$ forex system have positive effect on labor productivity for both models. Because of the superiority of GMM model in dynamic panel data models, it could be more appropriate to look at the GMM estimation results rather than OLS results. According to GMM model, the coefficients for large scale and small scale privatization and trade\&forex system are found to be significant for the transition period. While large scale privatization affects labor productivity negatively, small scale privatization 
affects the labor productivity positively. Also, trade and forex system support the labor productivity from positive side. This result overlaps with the transition economies' attitudes toward to reforms.

Finally, it is a fact that the transition process hasn't finished yet. The transition countries still deal with the economic problems that came from the past. The performance of reform efforts is quite important for transition economies in enhancing the productivity performance i.e. their growth performance. According to EBRD (2014), the key factor for decreasing the discrepancies between the transition countries' labor productivity is giving more importance to innovation process. When transition economies are compared with the advanced countries, it is stated that low productivity of firms and lower percentage of highly productive firms are still valid for transition economies and hence lower average productivity at the country levels occurred.

\section{REFERENCES}

Abramovitz, M. (1986). Catching Up, Forging Ahead, and Falling Behind. The Journal of Economic History, 46(2), 385-406.

Baltagi, B. (2002). Econometric Analysis of Panel Data. Chichester: Wiley.

Barro, R. J., \& Martin, X. S. (2004). Economic Growth. London: MIT Press.

Baumol, W. (1986). Productivity Growth, Convergence, and Welfare: What the Long-Run Data Show. The American Economic Review, 76(5), 1072-1085.

Baumol, W. J., \& Wolff, E. N. (1988). Productivity Growth, Convergence, and Welfare: Reply. The American Economic Review, 78(5), 1155-1159.

Case, K. E., \& Fair, R. C. (2004). Principles of Economics. New Jersey: Pearson Prentice Hall.

Deliktas, E., \& Balc1lar, M. (2005). A Comparative analysis of Productivity Growth, Catch-up and Convergence in Transition Economies. Emerging Markets Finance and Trade, 41(1), 6-28.

Deliktas, E., \& Emsen, S. (2002). The Evaluation of Privatization Process in Kyrgyzstan: 1991-2001. In O. S. University (Ed.), International Science Conference in Modern Societies. Osh, Kyrgyzstan.

Dowrick, S., \& Nguyen, D. (1989). OECD Comparative Economic Growth 1950-85: CatchUp and Convergence. The American Review, 79(5), 1010-1030.

EBRD. (2013, January 20). Retrieved from http://www.ebrd.com/country/sector/econo/stats/index.htm 
EBRD. (2014, July 29). Transition Report. Retrieved from http://www.ebrd.com/news/publications/transition-report/transition-report-2014.html

Hinds, M. (1990). Issues in the Introduction of Market Forces in Eastern European Socialist Economies. EMENA Discussion Papers, IDP-0057.

Hsiao, C. (2003). Analysis of Panel Data. Cambridge: Cambridge University Press.

ILO. (2013, February 25). Retrieved from http://laborsta.ilo.org/

Islam, N. (1995). Growth Empirics:A Panel Data Approach. The Quarterly Journal of Economics, 110(4), 1127-1170.

Islam, N. (2003). What Do We Learnt from the Convergence Debate? Journal of Economic Surveys, 17(3), 309-362.

Kennedy, P. (2006). A Guide to Econometrics. USA: Wiley Blackwell.

Kok, R., \& Deliktas, E. (2004). Efficiency Convergence in Transition Economies: 1991-2002: A Non-Parametric Frontier Approach. Kyrgyz-Turkish Manas University Publication:61, Conference Series: 6 (pp. 260-280). Publication:61.

Lall, S., \& Y1lmaz, S. (2000). Regional Economic Convergence, Do Policy Instruments Make a Difference. World Bank Institute.

Lipton, D., \& Sach, J. (1990). Creating a Market Economy in Eastern Europe: The Case of Poland. Brookings Papers on Economics Activity, 1, 75-147.

Matheson, T. D., \& Oxley, L. (2007). Convergence in Productivity Across Industries: Some Results for New Zealand and Australia. International Review of Applied Economics, 21(1), 55-73.

Onder, O., Deliktas, E., \& Karadag, M. (2006). Kamu Sermaye Stokunun Türkiye'de Bölgesel Yakınsamaya Etkisi. The Scientific and Technological Research Council of Turkey (TUBITAK ), Social and Human Sciences Research Grant Group.

Osiewalski, J., Koop, G., \& Steel, M. (1998). A Stochastic Frontier Analysis of Output Level and Growth in Poland and Western Economies. Center for Economic Reseach Working Paper, 9785.

Polanec, S. (2004). Convergence at Last? Evidence from Transition Countries. LICOS Discussion Papers, 14404.

Rao, D., S. Prasada, \& Coelli, T. (1998). Catch-Up and Convergence in Global Agricultural Productivity 1980-1995. Centre for Efficiency and Productivity Analysis Working Paper, 4(98). 
Roaf, J., Atoyan, R., Joshi, B., \& Krogulski, K. (2014). 25 Years of Transition PostCommunist Europe and the IMF.

Sala-i-Martin, X. (1996). The Classical Approach to Convergence Analysis. The Economic Journal, 106(437), 1019-1036.

Tansel, A., \& Gungor, N. (1997). Income and Growth Convergence: An Application to the Provinces of Turkey. First Annual ERC/METU Conference on Economics.

UNECE. (2013, January 20). Retrieved from http://w3.unece.org/pxweb/Dialog/

Yurtsever, C. (2007). Labour Productivity Convergence of Advanced European Countries across the Industries. 